\title{
ADDITION OF ACETYL-CYSTEINE TO CLOMIPHENE CITRATE FOR INDUCTION OF OVULATION IN ICSI CYCLES
}

Toppozada T. M., Shams A. T., El-Maghraby H. A., El-Samra M. A., Farahat, N.M.G., and Abd El-Samie A. A.

Department of Obstetrics and Gynecology, Alexandria and Fayoum Universities and Dept. of Clinical Pathology, Alexandria University.

\section{ABSTRACT}

Objective : Evaluation of the effect on N-Acetyl cysteine (NAC) as an adjuvant therapy to ovulation induction using clomiphene citrate (CC) in cases prepared for Intra-cytoplasmic - sperm injection (ICSI).

Design : Prospective randomized controlled study.

Material and Methods : Forty infertile women (male factor or tubal factor infertility) were included in the study in two equal groups (20 each) selected at random (Group I): controls: recciving $50 \mathrm{mg} \mathrm{CC}$ tablets twice daily from day 2-6 of the cycle, (Group II): study group: receiving, in addition to the same dose of CC, Acetyl cysteine (1200 mg tds/day) from day 2 to day 8 of the cycle. The patients were monitored using serial transvaginal ultrasound, and serum E2, FSH and progesterone were measured as well as urinary LH levels. The two groups were compared regarding the outcomes which included th enumber and qualtiy of oocytes, fertilization, embryo-transfer, and pregnancy and abotion rates..

Results : There were no statistically significant differences between the two groups regarding the outcomes (fertilization, embryo transfer, pregnancy rates, abortion rates, cleavage and oocyte maturity and quality). However, there was a trend (non-significant) towards an increase in mitotic figures in granulosa cells of the group receiving NAC. Conclusion: Despite the lack of statistical significance between the outcome data of the two groups, there was a trend towards an increase in pregnancy and abortion rates as well as mitotic figures in granulosa cells in the NAC group. A larger number of cases would probably provide more meaningful conclusions.

\section{INTRODUCTION}

In comparison with IVF using GnRH analogue plus FSH, low stimulation regimens require more cycles to obtain a comparable pregnancy rate, primarily due to a higher cycle cancellation rate. Low stimulation regimens, are associated with less prominent hormone side-effects, minimal risk of ovarian hyperstimulation syndrome, a much shorter duration of treatment and a reduction of the risk of multiple pregnancies. ${ }^{(1)}$ Almost all the improvements in IVF techniques have one main final goal: the improvement of the success rate which can help couples to have children (2).

It is time to propose a more gentle assisted reproductive technology-that is referred to as "friendly" IVF. ${ }^{(3,4)}$ simplification of the stimulation protocol can go in various directions such as reducing the amount of drug used, reducing the amount of control procedures involved in the monitoring of the cycle. Also, improving our knowledge on embryo implantation and our in-vitro handing of gametes and

Corresponding author : Toppozada, T. M., Dept. of Ob. \& Gyn., Fayoum university, Fayoum, Egypt. 
embryos to give the best implantation rates are future goals to achieve ${ }^{(5)}$.

Clomiphene citrate (alone) as an ovulation enhancing medication has been used (infrequently) during IVF. Usually, clomiphene (doses up to $150 \mathrm{mg}$ a day for 5-8 days) has been used starting between cycle days 2 and 5 with hCG to trigger ovulation when the lead follicle has reached a diameter of $17-18 \mathrm{~mm}$. Clomiphene citratc is not effective as gonadotropins for ovulation enhancement, so interest in its use as a single agent during controlled ovarian hyperstimulation and IVF has been low. Clomiphene in IVF cycles have a high cancellation rate due to poor follicular development, small numbers of developing follicles and premature LH surge. ${ }^{(6)}$

Ovarian stimulation using clomiphene citrate, combined with adjuvant treatments in order to achieve better results is being evaluated in many studies, all aiming to improve the outcome with lower costs. Adjuvant treatments have been tried and include the use of many drugs, such as vitamins, antioxidants, eltroxin, metformin, or bromocriptine to help in getting a better outcome.

N-Acetyl-Cysteine (NAC) is an acetylated form of the amino acid cysteine. NAC is a powerful antioxidant and a premier antitoxin and immune support substance, and as such is considered by some as an important life extension supplement. Antioxidants neutralize free radicals, which are produced by normal metabolic activity. When free radicals are left unchecked they cause damage to cells and DNA and are considered by scientists to be a major factor in the cancer and aging process. NAC appears to act as a survival factor in both male and female germ cells, and also in other cell types of the ovarian cortex ${ }^{(7-9)}$.

\section{MATERIALS \& METHODS}

The aim of this work is to:

- Compare oocyte maturity, fertilization and cleavage in two groups of patients (receiving clomiphene citrate with or without $\mathrm{N}$-acetyl-L-cysteine (NAC).

Also, to compare pregnancy and abortion rates in the two groups and to study the effect of (NAC)therapy on mitotic figures of granulosa cells of clomiphene citrate stimulated females.

\section{Methods :}

All the 40 cases enrolled in this study consented to participate. After history taking, general and gynecological examinations, the body mass index was calculated, basal U/S (vaginal probe Medison sonoace 3200) scanning was performed to assess basal follicular count and exclude any pelvic pathology.

All the patients presented standard basal values of serum $E_{2}$ and $\mathrm{FSH}$ (performed on the $3^{\text {rd }}$ day of the cycle) and male partners were assessed according to their semen analysis as well. After confirmation of the cause of infertility in these 40 patients, they were included on a random basis into 2 groups, each consisting of 20 subjects.

\section{Group A: (20 patients)}

Patients in group A were given oral clomiphene citrate (Global napi Pharm., Aventis pharma SAE) 50 $\mathrm{mg}$ twic e daily for 5 days, starting on day 2 of the cycle to day 6.

\section{Group B: (20 patients)}

Patients in group B were given clomiphene citrate $50 \mathrm{mg}$ (bid) similar to group A plus $1200 \mathrm{mg} /$ day NAC by oral administration on half a glass of water on 3 divided doses ( 2 sachets/dose) from day 2 to day 8 of the cycle.

\section{Monitoring:}

following onset of induction of ovulation, all patients were scanned every other day starting at the end of the first week after ovulation induction. Cases showing evidence of follicular growth (where a 
follicle measuring $18 \mathrm{~mm}$ was seen) and increase in endometrial thickness ( $>7 \mathrm{~mm}$ ) were monitored more closely (on a daily basis) in the periovulatory period; the scanning was done using the vaginal probe of the Medison Sonoace 3200.

Serum progesterone was measured on the day of hCG administration (follicle diameter of $18-20 \mathrm{~mm}$-endometrial thickness $9-10 \mathrm{~mm}$ and serum -E2 levels of $1000-1500 \mathrm{pg} / \mathrm{ml}$ ), done by Electrochemicalimmunoassy (ELICA) using the progesterone II reagent kit (Cat. No. 12145383 Roche).

Serial urinary LH levels were evaluated coinciding with the follicular growth in order to detect any rise in LH levels using the Ovulation test device (CAT: FLH- 102 LOT: LH 21206, ACON laboratories, Inc. USA).

\section{Oocyte retrieval:}

Timing of i.m. HCG (10,000 IU. Pregnyl@, Organon, Egypt) was planned according to follicular size $(18-20 \mathrm{~mm})$ and endometrial thickness $>8 \mathrm{~mm}$. Transvaginal guided oocyte retrieval was done 34-36 hours afterwards using the vaginal $u / s$ and a laboratoire CCD aspiration needle with a gauge of $17-\mathrm{LG} 300 \mathrm{~mm}$ and a syringe $20 \mathrm{ml}$ BD discodit II under sedation with Deprivan® (Zeneca Pharmaceuticals).

Following retrieval, oocytes were washed three times in Ham's F 10, serum free medium and were finally incubated in IVF medium droplets under oil (Scandinavian IVF science, Gothenberg, Sweden). The oocyte cumulus cells were removed enzymatically using ready made $10 \%$ hyaluronidase. Before cumulus was completely dissociated, oocytes were moved into HEPES- buffered medium where corona removal was performed mechanically by repeated pippetting through finely polished glass pipette, until no more cells were seen attached to zona pellucida. Semen was prepared by double wash and resuspension. Metaphase II oocytes only were injected, and motile morphologically normal sperm was selected for injection. It was moved to the PVP droplet in the micro-injection dish, immobilized, and aspirated tail first into the injection pipette. Fertilization was checked after 16 to 18 hrs and embryos were evaluated 48 hrs after retrieval. Class A embryos were defined as those with equal regular blastomeres. Also, pregnancy and bortion rates were recorded.

The effect of NAC on the mitotic ligures of granulosa cells of the clomiphene citrate stimulated patients were studied using floweytometry. Flow cytometric analysis of differentially stained normal and tumor cells is used for research in the identification of abnormal DNA stemline and 10 estimate the DNA index (DI) and cell-cycle phatse distributions of these stemlines (10-12).

the method involves dissolving the cell membrane lipids with a nonionic detergent, eliminating the eell cytoskcleton and nuclear proteins with trypsin, digesting the cellular RNA with an enzyme, and stabilizing the nuclear chromatin with spermine. Propodium iodide (PI) is stiometrically bound to the clean, isolated nuclei which are then run on a llow cytometer equipped with electronic doublediscremination capability (13-15).

\section{RESULTS}

The age of the patients ranged between 21-39 years, with a mean of 30.2 years. The patients had their BMI $\left(\mathrm{Kg} / \mathrm{m}^{2}\right)$ ranging between 20.2-29.3 with a mean of 25.16 .

There was no significant statistical difference between the two groups as regards their mean age and BMI.

Comparison between serum FSH $(\mathrm{mIU} / \mathrm{ml})$ and E2 $(\mathrm{pg} / \mathrm{ml})$ levels on day 3 of cycle in both groups showed that there was also no significant statistical difference. Also, comparison between serum 
progesterone ( $\mathrm{ng} / \mathrm{m} \mathrm{l}$ ) levels on the day of HCG in both groups of patients showed that there was no significant statistical difference between both groups. Comparison between the cause of infertility (whether male or tubal factors) in both groups of patients showed No significant differences as wall. There was no difference between having a history of previous IUI or ICSI between the 2 groups (Table I)

Comparison between stages of maturity of oocytes whether M2 or G.V between both groups showed no significant statistical difference between M2 stage of maturity G.V stage between the 2 groups (Table II).

Comparison of the number and percentage of embryos transferred between btoh groups: showed no significant difference (Table III)

Also, there was no significant statistical difference in fertilization, pregnancy or post transfer abortion rates betwen the 2 groups (Table III). There was no significant statistical difference between the 2 groups regarding cleavage and number of divided cells (Table III).

Table I : Causes of infertility in both groups.

\begin{tabular}{|c|c|c|c|c|c|}
\hline & \multicolumn{2}{|c|}{$\begin{array}{c}\text { Group A } \\
\quad(\mathbf{C C}) \\
(\mathbf{n}=\mathbf{2 0})\end{array}$} & \multicolumn{2}{|c|}{$\begin{array}{c}\text { Group B } \\
(C C+N A C) \\
(n=20)\end{array}$} & \multirow[t]{2}{*}{$\begin{array}{l}\text { Chi Sq. } \chi^{2} \\
\text { (P Value) }\end{array}$} \\
\hline & $\mathbf{n}$ & $\%$ & n & $\%$ & \\
\hline Male factor & 12 & 60 & 12 & 60 & $N A$ \\
\hline Tubil factor & 8 & 40 & 8 & 40 & $\mathrm{NA}$ \\
\hline Previous IUI & 0 & 0 & 3 & 15 & $3.243 \quad(p=0.072 \mathrm{NS})$ \\
\hline Previous ICSI & 0 & 0 & 2 & 10 & $2.105 \quad(p=0.147 N S)$ \\
\hline
\end{tabular}

NA : Non applicable statistics (duc to equal percentages)

NS : Non signiticant difference ( $p>0.05$ )

Table II : Stages of maturity.

\begin{tabular}{|c|c|c|c|c|c|}
\hline & \multicolumn{2}{|c|}{$\begin{array}{c}\text { Group A } \\
\text { (CC) } \\
(n=20)\end{array}$} & \multicolumn{2}{|c|}{$\begin{array}{c}\text { Group B } \\
(C C+N A C) \\
(n=20)\end{array}$} & \multirow[t]{2}{*}{$\begin{array}{c}\text { Chi Sq. } \chi^{2} \\
\text { (P Value) }\end{array}$} \\
\hline & $\mathbf{n}$ & $\%$ & $\mathrm{n}$ & $\%$ & \\
\hline \multicolumn{6}{|c|}{$\begin{array}{l}\text { Number of oocytes in M2 } \\
\text { slage }\end{array}$} \\
\hline 1 & 5 & 25.0 & 5 & 25.0 & 2.600 \\
\hline 2 & 7 & 35.0 & 3 & 15.0 & $p=0.457$ \\
\hline 3 & 2 & 10.0 & 2 & 10.0 & NS \\
\hline \multicolumn{6}{|l|}{ GV } \\
\hline I & 4 & 20.0 & 1 & 5.0 & 2.918 \\
\hline 2 & 0 & 0.0 & 0 & 0.0 & $p=0.233$ \\
\hline 3 & 0 & 0.0 & 1 & 5.0 & NS \\
\hline
\end{tabular}

NS : Non significant difference $(p>0.05)$

Egypt. J. Fertil. Steril. 
Table III :

\begin{tabular}{|c|c|c|c|c|c|}
\hline & & & & & $\begin{array}{l}\text { Chi Sq. } \chi^{2} \\
\text { (P Value) }\end{array}$ \\
\hline & $\mathbf{n}$ & $\%$ & $\mathbf{n}$ & $\%$ & \\
\hline Embryo transfer & & & & & \\
\hline 1 & 12 & 60.0 & 8 & 40.0 & 0.720 \\
\hline 2 & 6 & 30.0 & 2 & 10.0 & $p=0.698 \mathrm{NS}$ \\
\hline 3 & 1 & 5.0 & 1 & 5.0 & \\
\hline Fertilization rate & 13 & 65 & 8 & 40 & $\begin{aligned} & 2.506 \\
p & =0.113 \mathrm{NS} \\
Z & =1.563 \\
P & =0.118 \mathrm{NS}\end{aligned}$ \\
\hline Cleavage & 12 & 60 & 8 & 40 & $\begin{array}{c}1.600 \\
P=0.206 \mathrm{NS} \\
Z=1.249 \\
P=0.212 \mathrm{NS}\end{array}$ \\
\hline Number of divided cells & & & & & \\
\hline 2 & 2 & 10.0 & 1 & 5.0 & 0.150 \\
\hline 4 & 5 & 25.0 & 3 & 15.0 & $p=0.927 \mathrm{NS}$ \\
\hline 6 & 5 & 25.0 & 4 & 20.0 & \\
\hline Pregnancy rate & 3 & 15 & 5 & 25 & $\begin{array}{c}0.625 \\
p=0.429 \mathrm{NS} \\
\mathrm{Z}=0.781 \\
\mathrm{p}=0.435 \mathrm{NS}\end{array}$ \\
\hline Abortion & 0 & 0.0 & 3 & 15.0 & $\begin{aligned} & 3.243 \\
P= & 0.072 \mathrm{NS} \\
Z & =1.778 \\
P= & 0.075 \mathrm{NS}\end{aligned}$ \\
\hline
\end{tabular}

NS : Non signilicant difference $(p>0.05)$

$\mathrm{Z}$ : Non-parametric Mann-Whitney test

Comparison of the flowcytometric outcome regarding the mitotic activity of granulosa cells in the two groups, there was no statistical difference between the two groups as regards the DNA index i.e. The milotic aclivity. But there were 3 cases recorded in group B (NAC group) having hyperdiploid activity (increased mitotic activity) 


\section{DISCUSSION}

Controlled ovarian hyperstimulation $(\mathrm{COH})$ for IVF/ICSI patients has been an issue of research for years. Reaching best results with minimal costs has been the goal of such researches. Better results include aiming for higher fertilization rates, pregnancy rates, lower abortion rates and minimal side effects as ovarian hyperstimulation syndrome.

Natural cycle and low stimulation protocols have been used to induce ovualtion for IVF/ICSI. Adding adjuvant medications in order to achieve better results has been tried with many drugs. $\mathrm{N}$-acety $\mathrm{L}$ cysteine (NAC) has been lately used as an adjuvant therapy in induction of ovulation in polycystic ovary syndrome patients ${ }^{(16)}$.

Follicular atresia in the ovary is a natural phenomenon, eventually leading to exhaustion of the pool of primordial follicles. The discovery that this process is due to apoptosis has led to extensive research on follicular eell death ${ }^{(17)}$. NAC has been used to suppress eell death in human ovarian tissue cultures as well as in inhibiting apoptosis in human male germ cells in vitro ${ }^{(7,18)}$. In a study conducted by M. Otala et al (2002), NAC was found to inhibit apoptosis in human ovarian cell culture ${ }^{(18)}$

In another study, Rizk et al (2004) evaluated the use of NAC on PCOS patients. The objective was to evaluate the effect of NAC - a mucolytic drug with insulin sensitizing properties - as an adjuvant therapy in subjects with PCOS resistant to clomiphene citrate (CC). It was a placebo controlled, double blind randomized trial, conducted upon 150 patients diagnosed as CC resistant PCOS. Patients were assigned randomly to receive NAC $1.2 \mathrm{~g} /$ day or placebo with CC $100 \mathrm{mg} /$ day for 5 days starting at day 3 of the cycle. No cases of ovarian hyperstimulation syndrome were reported. The authors concluded from that study that NAC as an adjuvant to clomiphene citrate was more effective than placebo for $\mathrm{CC}$ resistant patients with $\mathrm{PCOS}^{(16)}$.

The present study was conducted on 40 non PCOS patients planned for ICSI. Our results showed a trend (non-significant) towards an increase in pregnancy and abortion rates in the NAC group while an increase was observed in fertilization rates and cleavage in the $\mathrm{CC}$ only group. This may indicate that NAC may act through better implantation as pregnancy rate is higher in this group despite lower maturation and fertilization rates. The actions of NAC has been suggested to be through an influence on insulin receptor activity, act as an antiapoptotic (19), an antioxidant protection against focal ischemia (20), inhibition of phospholipid metabolism, and by proinflammatory cytokine release and protease activity ${ }^{(21)}$. However the exact mechanism is not yet discovered. In our study, NAC was well tolerated by all the patients without manifest side effects.

To our knowledge, this is the first study to show mitotic activity through demonstration of the DNA index in granulosa cells using flowcytometry, indicating a possible effect on the cell cycle. The present results showed a similar outcome in both groups. In group A there were 19 cases with diploid DNA and with a DNA index of 1 indicating no mitotic activity at stage G0 of the cell cycle; also there was 1 case with no granulosa cells in the collected follicular fluid. In group B (NAC), there were 13 cases with diploid DNA and with DNA index 1 but there were 3 cases having hyperdiploid DNA in GI stage. Although these data indicated no significant differences between the 2 groups, yet the difference in mitotic activity may indicate better oocyte quality in the NAC group and further evaluation in more cases may Clarify this issue. 


\section{REFERENCES}

1. Ingerslev, H.J., Hojgaard, A., Hindkjaer, et al. A randomized study comparing IVF in the unstimulated cycle with IVF following clomiphene citrate. Hum. Repord., 2001; 16, 696-702.

2. Rosenwaks, $Z$., davis, $O$. and damario, $M$. The role of maternal agein assisted reporoduction. Hum. Reprod., 1995; 10 (Suppl. 1), 165-173.

3. Steptoc P. and Edwards R. birth after the reimplantation of a human embryo. Lancet, 1978; 7. 336.

4. Navol, D., Rosenwaks, Z., Anderson, F. and Hodgen, G. D. Gonadotropin releasing hormone agonist-induced ovarian hyperstimulation: low dose side effect in women and monkeys. Fertil. Steril., 1991; 55, 1069-1075.

5. Van Blerkom, J. can the developmental competence or early human embryos be predicted effectively in the clinical IVF laboratory? Hum. Reprod, 1997; 12, 1610-1614.

6. Fiedler $\mathrm{K}$, Ludwing $\mathrm{m}$. use of clomiphene citrate in vitro fertilization (IVF) and IVF/intracytoplasmic sperm injection cycles. Fertil Steril. 2003 Dec., 80 (6): 1521-3.

7. Erkkila, K., Hirvonen V., Wuokko, E., Parvinen, M. and Dunkel, L. N-Acetyl-L-cysteine inhibits apoptosis a set of methods for sample-storage, staining, and internal standzrdization. Cytometry. 1983; 3: 332-339.

8. Lee, C. K., Weaks, R. L.; Johnson G. A., Bazer F. W., and Piedrahita J. A. Effects of protease inhibitors and antioxidants on in-vitro survival of porcine primordial germ-cells. Biol. Reprod., 2000, 63: 887-897.

9. Roederer M., Ela S. W., stall F. J., Herzenberg L. A. $\mathrm{N}$-acetylcysteine a new approach to anti-HIV therapy. Aids Res. Hum. Retrovir, 1992, 8: 209-217.

10. Bach BA, Knape WA, Edinger MG, Tubbs RR. Improved sensitivity and solution in the flow cytometric DNA analysis of human solid tumor specimens. Am J Clin Pathol. 1991; 96: 615-627.

11. emdin SO, Stenling R, Roos G. Prognostic value of DNA content in colorectal carcinoma: A flow cytometric study with some metha plogic aspects. Cancer. 1987; 60: 1282-1287.

12. Frierson HF. Flow cytometric analysis of ploidy in solid neoplasms: Comparison of fresh tissue with formalin-fixed paraffin-embedded specimens. Hum Pathol. 1988; 19: 290-294.

13. Vindelov LL, Christensen IJ, Nissen NI. A detergent-trypsin method for hte preparation of nuclei for flow eytometric DNA analysis. Cytometry. 1983; 3: 323-327.

14. Vindelov LL, Christensen IJ, Jensen G, Nissen NI. Limits of detection of nuclear DNA abnormalities by flow cytometric DNA analysis. Results obtained by a set of methods for sample-storage, staining, and internal standardization. Cytometry. 1983; 3: 332-339.

15. Humason, GL. Staining hematologic elements and related tissues In: Bartlet AC, ed. Animal Tissue Techniques. San Francisco: W.H. Freeman \& Company; 1979: 229-230.

16. Rizk A Y, Bedaiwy M A, Al-Inany H G, N-Acelyl cysteine is a novel adjuvant to clomiphene citrate in resistant polycystic ovary syndrome patients: 2004; $19^{\text {th }}$ Annual mecting of the European society of Human Reproduction and Embryology.

17. Morita, Y. and Tilly, J. L. Oocyte apoptosis: like sand through an hourglass. Dev. Biol. (Orlando), 1999; 213,1-17.

18. M. Otala, K. Erkkila, T. Tuuri, J. Sjoberg, L. Suomalainen, A-M. Suikkaria, V. Pentikainen and L. Dunkel. Cell death and its suppression in human ovarian tissuc culture. mol Hum Rep. 2002; 8: 3, 228-236.

19. Odetti, P., Pesce, C., Traverso, N., Mrninin, S., Maineri, E. P., Cosso, L., valentine, S., Patriarca S., Cottalasso, D., marinari, U. M. and Pronzato, M. A. Comparative trial of $\mathrm{N}$-acetyl-cysteine, traurine, and oxerutin on skin and kidney damage in long-term experimental diabetes. Diabetes, 2003; 52, 499-505. 
20. De Maltia, G., Bravi, M. C., Laurenti, O., Cassone-Faldetta, M., Proietli, A., De Luca, O., Armiento, A., Ferri, C, reduction of oxidative stress by oral $\mathrm{N}$-acetyl-L-Cysteine treatment decreases plasma soluble vascular cell adhesion moleculeleoncentrations in non-obese, non-dyslipdasmic, normotensive, patients with non-insulin-dependent diabetwes. Diabetologia, 1988; 41, 1392-1396.

21. Sekhan, B., Sekhon, C., Khan, M., Patel, S. J., Singh, I. and Singh, A. K. N-Acetyl Cysteine protects against injury in a rate model of focal ccrebral ischemia. Brain Res, 2003; 971, 1-8. 